\title{
Review \\ Bench-to-bedside review: Angiopoietin signalling in critical illness - a future target?
}

\author{
Matijs van Meurs ${ }^{1,2}$, Philipp Kümpers ${ }^{3}$, Jack JM Ligtenberg ${ }^{1}$, John HJM Meertens ${ }^{1}$, \\ Grietje Molema ${ }^{2}$ and Jan G Zijlstra ${ }^{1}$
}

\begin{abstract}
${ }^{1}$ Department of Critical Care, University Medical Center Groningen, University of Groningen, 9700RB Groningen, The Netherlands 2Department of Pathology and Medical Biology, Medical Biology Section, University Medical Center Groningen, University of Groningen, HPC EA11, PO Box 30.0019700 RB Groningen, The Netherlands

${ }^{3}$ Department of Nephrology \& Hypertension, Hanover Medical School, Carl-Neuberg-strasse 1, Hannover, D 30171, Germany
\end{abstract}

Corresponding author: Jan G Zijlstra, j.g.zijlstra@int.umcg.nl

Published: 9 March 2009

This article is online at http://ccforum.com/content/13/2/207

(c) 2009 BioMed Central Ltd

Critical Care 2009, 13:207 (doi:10.1186/cc7153)

\begin{abstract}
Multiple organ dysfunction syndrome (MODS) occurs in response to major insults such as sepsis, severe haemorrhage, trauma, major surgery and pancreatitis. The mortality rate is high despite intensive supportive care. The pathophysiological mechanism underlying MODS are not entirely clear, although several have been proposed. Overwhelming inflammation, immunoparesis, occult oxygen debt and other mechanisms have been investigated, and - despite many unanswered questions - therapies targeting these mechanisms have been developed. Unfortunately, only a few interventions, usually those targeting multiple mechanisms at the same time, have appeared to be beneficial. We clearly need to understand better the mechanisms that underlie MODS. The endothelium certainly plays an active role in MODS. It functions at the intersection of several systems, including inflammation, coagulation, haemodynamics, fluid and electrolyte balance, and cell migration. An important regulator of these systems is the angiopoietin/ Tie2 signalling system. In this review we describe this signalling system, giving special attention to what is known about it in critically ill patients and its potential as a target for therapy.
\end{abstract}

\section{Introduction}

Critical illness is a life-threatening disease by definition. Patients treated for critical illness in the intensive care unit have underlying causes such as infection, trauma, major surgery, hemorrhagic shock, pancreatitis and other major insults. Despite maximal supportive care, severely ill patients treated in intensive care units are still likely to die, usually after an episode of increasing failure of multiple organs [1].

The mechanisms that underlie multiple organ dysfunction syndrome (MODS) are not known [2], although several have been proposed, including overwhelming infection or immune response, immune paralysis, occult oxygen debt and mitochondrial dysfunction [3-5]. Although these potential mechanisms have features in common, it is not clear whether MODS is a final common pathway or when it is engaged. The innate and adaptive immune systems, coagulation, and hormonal and neuronal signalling are undoubtedly involved and are all connected. For example, the hypoxic response is linked to innate immunity and inflammation by the transcription factor nuclear factor- $\kappa B(N F-\kappa B)[6]$. It is no coincidence that the few interventions that appear to be of benefit, although this is still under debate, have pleiotropic mechanisms of action [7-9]. Thus, it seems reasonable to study the intersections between and within cellular and molecular systems to elucidate the interactions and to develop therapeutic options.

One of the central cellular players in this system is the endothelial cell (EC). Once thought to serve as an inert vascular lining, ECs are highly heterogeneous and constitute an active disseminated organ throughout the circulatory system. ECs form the border between every organ and the bloodstream and thus with the rest of the body. The EC receives and gives signals, stores active substances of multiple systems, and regulates the passage of fluids, electrolytes, proteins and cells. The EC has a time and place dependent phenotype that is dynamically controlled, and its reactions to stimuli are specific to organ and vascular bed [10-13]. The EC merits robust investigation in critical illness, as in vascular medicine [14].

ECs fulfil three functions. First, they participate in the formation of new blood vessels. This is important in embryo-

Ang = angiopoietin; Ang/Tie system = angiopoietin/Tie2 signalling system; EC = endothelial cell; HUVEC = human umbilical vein endothelial cell; LPS = lipopolysaccharide; MODS = multiple organ dysfunction syndrome; NF- $\mathrm{KB}=$ nuclear factor- $\mathrm{KB} ; \mathrm{PI} 3 \mathrm{~K}=$ phosphoinositide-3 kinase; TNF $=$ tumour necrosis factor; VEGF = vascular endothelial growth factor; WPB $=$ Weibel-Palade body. 
genesis and organogenesis in normal physiology and in wound repair, but it is considered pathologic in tumour growth and diabetes [15]. Second, in the adult organism, ECs help to maintain homeostasis, including fluid, electrolyte and protein transport, and cell migration into and out of the vessel, and to regulate blood flow. Third, ECs react and respond to disturbances of homeostasis (for example, in inflammation, coagulation and hypoxia/reperfusion).

All three functions are involved in MODS, in which ECs are shed, blood flow regulation is hampered, vessels become leaky, cells migrate out of the vessel and into the surrounding tissue, and coagulation and inflammation pathways are activated [16]. The machinery involved - receptors, signalling pathways and effectors - is largely the same in each function, but the net effect is determined by the balance between the parts of the machinery and the context [15].

The angiopoietin/Tie2 signalling system (Ang/Tie system) appears to be crucial in all three functions [17,18]. The Ang/Tie system, which was discovered after vascular endothelial growth factor (VEGF) and its receptors, is mainly restricted to EC regulation and is the focus of this review. Accumulating evidence suggests that this system is nonredundant and is involved in multiple MODS-related pathways. All components of potential pathophysiological mechanisms in MODS should be viewed within their own context, because all systems are mutually dependent. Thus, examination of the Ang/Tie system might offer insight into the mechanisms underlying MODS and provide opportunities for therapeutic intervention.

\section{Is the Ang/Tie system involved in critical illness?}

The notion that the Ang/Tie system contributes to disease pathogenesis is supported by clinical studies and studies in animal models, and by the relation between symptoms of critical illness and disturbances in this system. In mice, Ang-2 over-expression in glomeruli causes proteinuria and apoptosis of glomerular ECs [19]. In a rat model of glomerulonephritis, Tie2 is over-expressed by ECs, and Ang-1 and Ang-2 are over-expressed by podocytes in a time-dependent manner during the repair phase [20]. Therefore, Ang/Tie might be involved in renal failure and repair.

Lung dysfunction is common in critical illness, and evidence of Ang/Tie involvement has been found in animal models. In a rat model of acute respiratory distress syndrome, Ang-1 reduces permeability and inflammation, whereas Tie2 deficiency increases damage [21]. In an experimental model of asthma, Ang-1 mRNA was decreased, and Ang-1 supplementation decreased alveolar leakage and NF- $\mathrm{B} B$-dependent inflammation [22]. In hypoxia-induced pulmonary hypertension in rats, decreased activity of the Tie 2 pathway contributed to right ventricular load, and this effect was antagonized by Ang-1 [23]. On the other hand, a causative role for Ang-1 in pulmonary hypertension has also been suggested [24]. In hyperoxic lung injury, Ang-2 is involved in lung permeability and inflammation [25].

Ang/Tie also may contribute to critical illness in patients with pulmonary conditions. Ang-1 and Ang-2 concentrations in sputum from asthma patients correlated with airway microvascular permeability [26]. In patients with exudative pleural effusion, the Ang-2 level was increased whereas Ang-1 was unchanged [27]. Ang-2 levels are associated with pulmonary vascular leakage and the severity of acute lung injury. Plasma from patients with acute lung injury and high Ang-2 concentrations disrupts junctional architecture in vitro in human microvascular ECs $[28,29]$.

Patients with cardiovascular disorders also exhibit changes in the Ang/Tie system. Circulating Ang-1 concentrations are stable in patients with atrial fibrillation, but Ang-2 concentrations are increased, along with markers of platelet activation, angiogenesis and inflammation [30]. Patients with hypertension resulting in end-organ damage have increased levels of circulating Ang-1, Ang-2, Tie2 and VEGF [31]. Congestive heart failure is associated with elevated plasma levels of Ang-2, Tie2 and VEGF, but normal levels of Ang-1 [32]. A similar pattern is seen in acute coronary syndrome [33].

Circulating levels of components of the Ang/Tie system have been measured in patients admitted to the critical care unit. In trauma patients plasma Ang-2, but not plasma Ang-1 or VEGF, was increased early after trauma, and the level correlated with disease severity and outcome [34]. In children with sepsis and septic shock, Ang-2 levels in plasma were increased and once again correlated with disease severity, whereas Ang-1 levels were decreased [35]. The same Ang-1/ Ang-2 pattern is seen in adults with sepsis [28,29,36-39]. The results of studies of the Ang/Tie system in humans are summarized in Table 1. In sepsis, VEGF and its soluble receptor sFLT-1 (soluble VEGFR-1) are also increased in a disease severity-dependent manner [40-42].The picture that emerges from these studies is that the Ang/Tie signalling system appears to play a crucial role in the symptoms of MODS. Findings in animal models and in patients suggest that Ang-1 stabilizes ECs and Ang-2 prepares them for action. The close relation with VEGF is also apparent.

\section{The angiopoietin signalling system Ligands and receptors}

The angiopoietin signalling system consists of four ligands and two receptors (Figure 1). The ligands are Ang-1 to Ang-4, the best studied being Ang-1 and Ang-2 [17,43-45]. The roles of Ang-3 (the murine orthologue of Ang-4) and Ang-4 are much less clear [18]. Angiopoietins are $70-\mathrm{kDa}$ glycoproteins that contain an amino-terminal angiopoietinspecific domain, a coiled-coil domain, a linker peptide and a carboxyl-terminal fibrinogen homology domain $[17,44,46,47]$. Ang-1 and Ang-2 bind to Tie 2 after polymerization of at least 


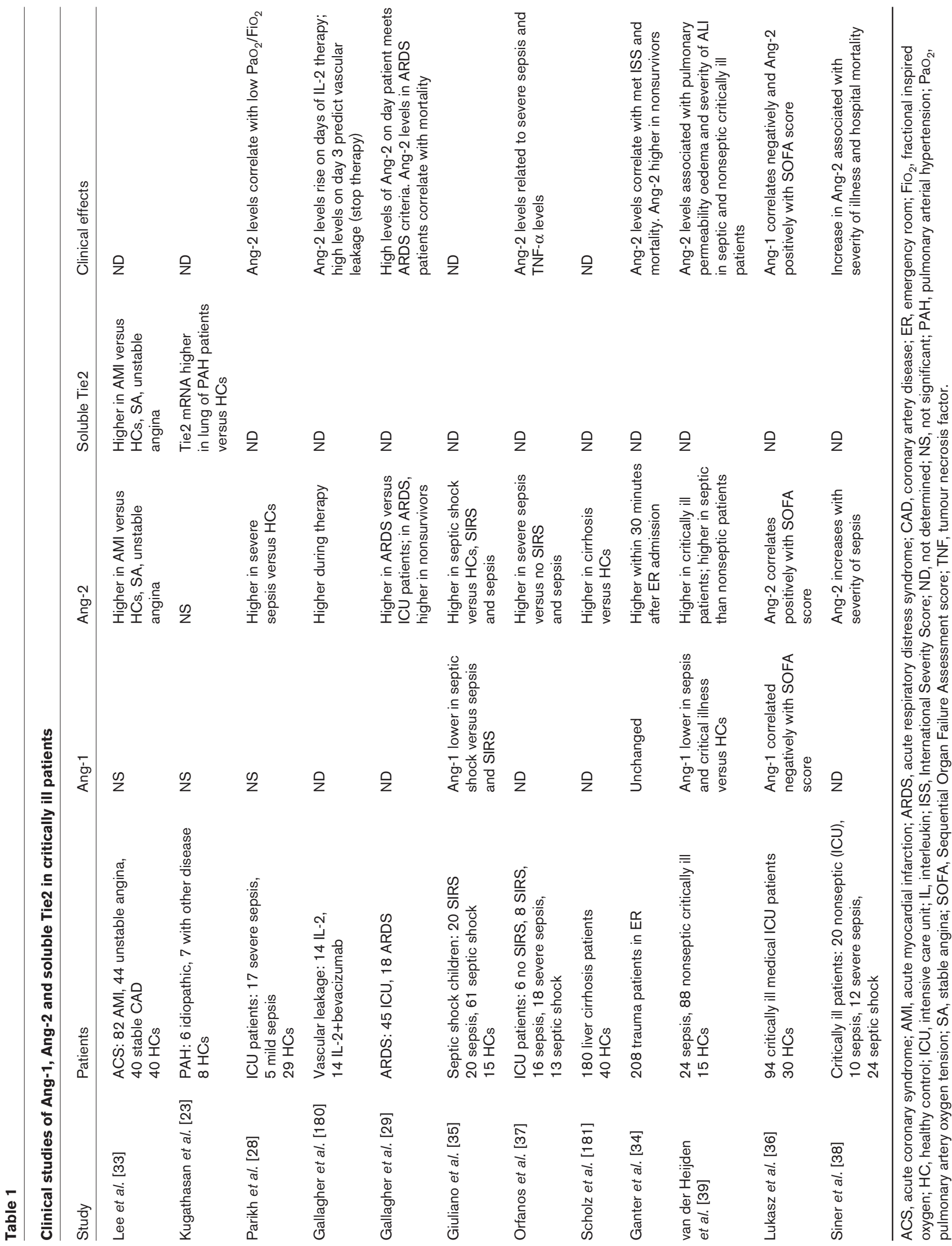


four (Ang-1) and two (Ang-2) subunits [48,49]. The dissimilarity between Ang-1 and Ang-2 signalling lies in subtle differences in the receptor binding domain that lead to distinct intracellular actions of the receptor; differential cellular handling of both receptor and ligands after binding and signalling initiation may also play a role $[49,50]$.

The receptors are Tie1 and Tie2 [51]. Tie2 is a $140-\mathrm{kDa}$ tyrosine kinase receptor with homology to immunoglobulin and epidermal growth factor $[47,52]$. Tie receptors have an amino-terminal ligand binding domain, a single transmembrane domain and an intracellular tyrosine kinase domain [51]. Ligand binding to the extracellular domain of Tie2 results in receptor dimerization, autophosphorylation and docking of adaptors, and coupling to intracellular signalling pathways [47,53-55]. Tie2 is shed from the EC and can be detected in soluble form in normal human serum and plasma; soluble Tie2 may be involved in ligand scavenging without signalling [56]. Tie2 shedding is both constitutive and induced; the latter can be controlled by VEGF via a pathway that is dependent on phosphoinositide-3 kinase (PI3K) and Akt [57]. Shed soluble Tie2 can scavenge Ang-1 and Ang-2 [56]. Tie1 does not act as a transmembrane kinase; rather, it regulates the binding of ligands to Tie2 and modulates its signalling [58-60].

\section{Origin of ligands and distribution of receptors}

Ang-1 is produced by pericytes and smooth muscle cells (Figure 1). In the glomerulus, which lacks pericytes, Ang-1 is produced by podocytes [61]. Ang-1 has a high affinity for the extracellular matrix, and so circulating levels do not reflect tissue levels, which in part is probably responsible for the constitutive phosphorylation of Tie2 in quiescent endothelium [62-65]. Ang-2 is produced in ECs and stored in WeibelPalade bodies (WPBs) $[66,67]$. The release of Ang-2 from WPBs by exocytosis can be regulated independently of the release of other stored proteins [68]. Tie2 is expressed predominantly by ECs, although some subsets of macrophages and multiple other cell types express Tie2 at low levels $[69,70]$. In ECs, Tie2 is most abundant in the endothelial caveolae [71].

\section{Genetics and transcriptional regulation of components of the Ang/Tie system}

The Ang-1 and Ang-2 genes are located on chromosome 8. Functional polymorphisms have not been identified in the Ang-1 gene, but three have been identified in the coding region of Ang-2 [72]. In ECs under stress, Ang-2 mRNA expression is induced by VEGF, fibroblast growth factor 2 and hypoxia [44,73]. Upregulation of Ang-2 induced by VEGF and hypoxia can be abolished by inhibiting tyrosine kinase or mitogen-activated protein kinase [73]. Ang-2 mRNA expression can be downregulated by Ang-1, Ang-2, or transforming growth factor [74]. After inhibition of PI3K by wortmannin, Ang-2 mRNA production is induced by the transcription factor FOXO1 (forkhead box O1) [75]. EC-specific Ang-2 promoter activity is regulated by Ets-1 and the Ets family member Elf-1 [76,77]. Because Tie2 signalling is required under circumstances that usually hamper cell metabolism, its promoter contains repeats that ensure transcription under difficult circumstances, including hypoxia [78].

\section{The Tie2 downstream signalling pathway}

Tie2 is present in phosphorylated form in quiescent and activated ECs throughout the body [62]. Signalling is initiated by autophosphorylation of Tie2 after Ang-1 binding and is conducted by several distinct pathways $[54,71,79,80]$. Tie2 can also be activated at cell-cell contacts when Ang-1 induces Tie2/Tie2 homotypic intercellular bridges [65]. In human umbilical vein endothelial cells (HUVECs), Ang/Tie signalling resulted in 86 upregulated genes and 49 downregulated genes $[81,82]$. Akt phosphorylation by PI3K with interaction of nitric oxide is the most important intracellular pathway [51,83-86]; however, ERK1/2, p38MAPK, and SAPK/JNK can also participate in Ang/Tie downstream signalling $[71,81,84,87-90]$. Endothelial barrier control by Ang-1 requires p190RhoGAP, a GTPase regulator that can modify the cytoskeleton [80]. The transcription factors FOXO1, activator protein-1, and NF-K B are involved in Ang/Tie-regulated gene transcription [75,91-93]. Ang-1induced signalling is has also been implicated in cell migration induced by reactive oxygen species [94]. ABIN-2 (A20-binding inhibitor of NF- $\mathrm{KB} 2$ ), an inhibitor of NF- $\mathrm{KB}$, is involved in Ang-1-regulated inhibition of endothelial apoptosis and inflammation in HUVECs [93]. However, the downstream signalling of Tie2 varies depending on cell type and localization and whether a cell-cell or cell-matrix interaction in involved, which results in spatiotemporally different patterns of gene expression. For example, Ang-1/Tie2 signalling leads to Akt activation within the context of cell-cell interaction, but it leads to ERK activation in the context of cell-matrix interaction. The microenvironment of the receptor in the cell membrane plays a central role in this signal differentiation. Adaptor molecules such as DOK and SHP2 and the availability of substrate determine which protein is phosphorylated [95].

\section{Signal regulation}

After binding of Ang-1, and to a lesser extent Ang-2, Tie2 is internalized and degraded, and Ang- 1 is shed in a reusable form [50]. VEGF is an important co-factor that can exert different effects on Ang-1 and Ang-2 signalling [88]. Ang-2 is antiapoptotic in the presence of VEGF but induces EC apoptosis in its absence [96]. Autophosphorylation and subsequent signalling are inhibited by heteropolymerization of Tie1 and Tie2 [59]. Although the Ang/Tie system appears to play its role mainly in paracrine and autocrine processes, its circulating components have been found in plasma. The significance of this finding in health and disease has yet to be determined.

\section{Summary}

The Ang/Tie system is an integrated, highly complex system of checks and balances (Figure 1) [45,54]. The response of 


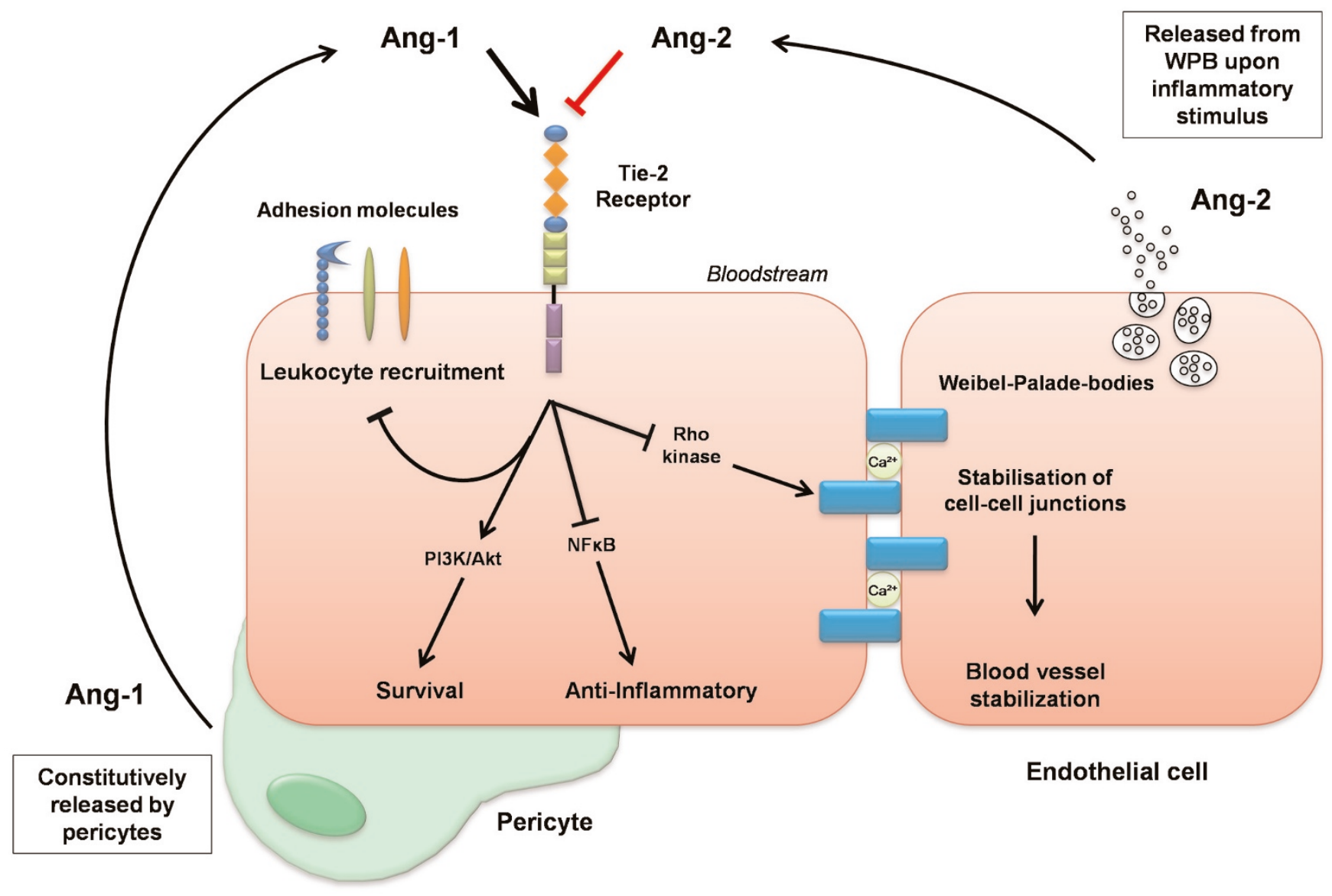

A schematic model of the angiopoietin-Tie2 ligand-receptor system. Quiescent endothelial cells are attached to pericytes that constitutively produce Ang-1. As a vascular maintenance factor, Ang-1 reacts with the endothelial tyrosine kinase receptor Tie2. Ligand binding to the extracellular domain of Tie2 results in receptor dimerization, autophosphorylation, docking of adaptors and coupling to intracellular signalling pathways. Signal transduction by Tie2 activates the PI3K/Akt cell survival signalling pathway, thereby leading to vascular stabilization. Tie2 activation also inhibits the NF-KB-dependent expression of inflammatory genes, such as those encoding luminal adhesion molecules (for example, intercellular adhesion molecule-1, vascular cell adhesion molecule-1 and E-selectin). Ang-2 is stored and rapidly released from WPBs in an autocrine and paracrine fashion upon stimulation by various inflammatory agents. Ang-2 acts as an antagonist of Ang-1, stops Tie2 signalling, and sensitizes endothelium to inflammatory mediators (for example, tumour necrosis factor- $\alpha$ ) or facilitates vascular endothelial growth factor-induced angiogenesis. Ang-2-mediated disruption of protective Ang-1/Tie2 signalling causes disassembly of cell-cell junctions via the Rho kinase pathway. In inflammation, this process causes capillary leakage and facilitates transmigration of leucocytes. In angiogenesis, loss of cell-cell contacts is a prerequisite for endothelial cell migration and new vessel formation. Ang, angiopoietin; NF- $\mathrm{KB}$, nuclear factor- $\mathrm{\kappa B}$; PI3K, phosphoinositide-3 kinase; WPB, Weibel-Palade body.

ECs to Ang-1 and Ang-2 depends on the location of the cells and the biological and biomechanical context [97,98]. It is believed that PI3K/Akt is among the most important downstream signalling pathways and that VEGF is one of the most important modulators of effects. Below we describe in more detail how this system responds to changes in homeostatic balances under various conditions of damage and repair.

\section{Ang/Tie signalling system in health and disease}

Angiogenesis, inflammation and homeostasis are highly related, and the Ang/Tie system lies at the intersection of all three processes $[99,100]$. The Ang/Tie system is critically important for angiogenesis during embryogenesis, but in healthy adults its function shifts toward maintenance of homeostasis and reaction to insults. Except for follicle formation, menstruation and pregnancy, angiogenesis in adults is disease related. Neoplasia-associated neoangiogenesis and neovascularization in diabetes and rheumatoid arthritis are unfavourable events, and improper angiogenesis is the subject of research in ischaemic disorders and atherosclerosis. Finally, failure to maintain homeostasis and an inappropriate reaction to injury are detrimental features in critical illness. 


\section{Angiogenesis}

Angiogenesis is dependent on multiple growth factors and receptors and their signalling systems and transcriptional regulators [101]. The process is complex and encompasses the recruitment of mobile ECs and endothelial progenitor cells, the proliferation and apoptosis of these cells, and reorganization of the surroundings [102]. To form stable new blood vessels, the response must be coordinated in time and space, and the Ang/Tie system is involved from beginning to end. To prepare for angiogenesis, Ang-2 destabilizes quiescent endothelium through an internal autocrine loop mechanism $[44,103]$. Before vascular sprouting starts, focal adhesion kinase and proteinases such as plasmin and metalloproteinases are excreted [85]. Often, this stage is preceded by activation of innate immunity and inflammation [104]. Apparently, the machinery to clean up after the work has been finished is installed before the work is commenced, again illustrating the close relations among the different processes [104].

Ang-1 maintains and, when required, restores the higher order architecture of growing blood vessels $[43,44,105,106]$. This is achieved by inhibiting apoptosis of ECs by Tie2mediated activation of PI3K/Akt signalling [107-109]. Ang-1/ Tie2 signalling is involved in angiogenesis induced by cyclic strain and hypoxia $[110,111]$. Although its role is less clear, Tie1 might be involved in EC reactions to shear stress [112]. Ang-1 is a chemoattractant for ECs [83-85], and both Ang-1 and Ang-2 have proliferative effects on those cells $[98,113]$. At the end of a vascular remodelling phase, Ang-2 induces apoptosis of ECs for vessel regression in competition with the survival signal of Ang-1 [106]. This apoptotic process requires macrophages, which are recruited by Ang-2 [70,114].

ECs require support from surrounding cells such as pericytes, podocytes, and smooth muscle cells [63]. These cells actively control vascular behaviour by producing signalling compounds (for instance, Ang-1 and VEGF) that govern the activity and response of ECs [61]. To attract ECs, Ang-1 secreted by support cells binds to the extracellular matrix. In quiescent ECs, this binding results in Tie2 movement to the site of cell-cell interaction. In mobile ECs, Ang-1 polarizes the cell with Tie2 movement abluminal site [65]. In tumour angiogenesis and in inflammation, Ang-2 recruits Tie2positive monocytes and causes them to release cytokines and adopt a pro-angiogenic phenotype [111].

\section{Homeostasis}

The Ang/Tie system provides vascular wall stability by inducing EC survival and vascular integrity. However, this stability can be disrupted by Ang- 2 injection, which in healthy mice causes oedema $[28,79,115,116]$ that can be blocked by systemic administration of soluble Tie2 [115]. Ang-2 can impair homeostatic capacity by disrupting cell-cell adhesion through E-cadherin discharge and EC contraction [28,117]. In contrast, through effects on intracellular signalling, the cytoskeleton and junction-related molecules, Ang-1 reduces leakage from inflamed venules by restricting the number and size of gaps that form at endothelial cell junctions $[80,118,119]$. Ang-1 also suppresses expression of tissue factor induced by VEGF and tumour necrosis factor (TNF)- $\alpha$, as well as expression of vascular cell adhesion molecule-1, intercellular adhesion molecule-1 and E-selectin. As a result, endothelial inflammation is suppressed [120-123].

In primary human glomerular ECs in vitro, Ang-1 stabilizes the endothelium by inhibiting angiogenesis, and VEGF increases water permeability [124]. Similar observations were made in bovine lung ECs and immortalized HUVECs, in which Ang-1 decreased permeability, adherence of polymorphonuclear leucocytes and interleukin-8 production [123].

\section{Injury}

Reaction to injury can be seen as an attempt to maintain homeostasis under exceptional conditions. ECs can be affected by several noxious mechanisms. The Ang/Tie system is considered crucial in fine-tuning their reaction to injury and in containing that reaction. Ang-2-deficient mice cannot mount an inflammatory response to peritonitis induced chemically or with Staphylococcus aureus [125], but they can mount a response to pneumonia, suggesting the existence of inflammatory reactions for which Ang-2 is not mandatory. Ang-2 sensitizes ECs to activation by inflammatory cytokines. In Ang-2-deficient mice, leucocytes do roll on activated endothelium but they are not firmly attached, owing to the lack of Ang-2-dependent upregulation of adhesion molecules and the dominance of Ang-1-regulated suppression of adhesion molecules [120-123,125].

In bovine retinal pericytes, hypoxia and VEGF induce Ang-1 and Tie2 gene expression acutely without altering Ang-2 mRNA levels. The opposite occurs in bovine aortic ECs and microvascular ECs, underscoring the heterogeneity of ECs from different microvascular beds [73,126,127].

Lipopolysaccharide (LPS) and pro-inflammatory cytokines can shift the Ang/Tie balance, rouse ECs from quiescence and provoke an inflammatory response. In rodents LPS injection induces expression of Ang- 2 mRNA and protein and reduces the levels of Ang-1, Tie2 and Tie2 phosphorylation in lung, liver and diaphragm within 24 hours, which may promote or maintain vascular leakage. The initial increase in permeability is probably due to release of Ang-2 stored in WPBs [39,128]. In a mouse model of LPS-induced lung injury, pulmonary oedema was found to be related to the balance between VEGF, Ang-1 and Ang-4 [129]. In a comparable model, Ang-1-producing transfected cells reduced alveolar inflammation and leakage [130].

In choroidal ECs, TNF induces Ang-2 mRNA and protein before affecting Ang-1 and VEGF levels [131]. In HUVECs, TNF-induced upregulation of Ang-2 is mediated by the NF- $\kappa B$ 
pathway [132], and TNF-induced Tie2 expression can be attenuated by both Ang-1 and Ang-2. Without TNF stimulation, only Ang-1 can reduce Tie2 expression [133]. Ang-2 sensitizes ECs to TNF, resulting in enhanced expression of intercellular adhesion molecule-1, vascular cell adhesion molecule-1 and E-selectin [74,125,134]. By inhibiting those endothelial adhesion molecules, Ang-1 decreases leucocyte adhesion [122].

Angiopoietins can mediate the synthesis of platelet-activating factor by ECs to stimulate inflammation [90]. Moreover, both Ang-1 and Ang-2 can translocate P-selectin from WPBs to the surface of the EC [135], and both can also increase neutrophil adhesion and chemotaxis and enhance those processes when they are induced by interleukin-8 $[86,136,137]$.

In a rat model of haemorrhagic shock, Ang-1 reduced vascular leakage, and it inhibited microvascular endothelial cell apoptosis in vitro and in vivo [107,138]. In this model, Ang-1promoted cell survival was partly controlled through integrin adhesion [139]. It has been suggested that EC apoptosis in haemorrhagic shock contributes to endothelial hyperpermeability [140-142]. Apoptosis is one of the reactions to MODSrelated injury as demonstrated in hypoxia/reperfusion [143].

\section{Cell adhesion}

Ang-1 and Ang-2 are involved in cell-cell and cell-matrix binding [139,144-146]. Endothelial permeability is greatly dependent on cell-cell adhesion. The major adherens junction is largely composed of vascular-endothelial cadherin. This complex can be disrupted by VEGF, leading to increased vascular permeability $[147,148]$, which can be antagonized by Ang-1 [149,150]. ECs can also bind to the matrix through the binding of Ang-1 to integrins, which can mediate some of the effects of Ang-1 without Tie2 phosphorylation [146,151]. At low Ang-1 concentrations, integrin and Tie2 can cooperate to stabilize ECs [151]. Ang-2 might play a role in inflammatory diseases such as vasculitis by disrupting the cell-cell junction and inducing denudation of the basal membrane [152]. Ang-1 can mediate the translocation of Tie2 to endothelial cell-cell contacts and induce Tie2-Tie2 bridges with signal pathway activation, leading to diminished paracellular permeability [65].

\section{Summary}

In the mature vessel, Ang-1 acts as a paracrine signal to maintain a quiescent status quo, whereas Ang-2 induces or facilitates an autocrine EC response [74,153]. In general, Ang-1 can be viewed as a stabilizing messenger, causing continuous Tie2 phosphorylation, and Ang-2 as a destabilizing messenger preparing for action [17]. Attempts to unravel the exact molecular mechanisms that control the system are complicated by microenvironment-dependent endothelial phenotypes and reactivity and by flow typedependent reactions to dynamic changes [13,154,155]. Hence, the EC must be viewed in the context of its surroundings - the pericyte at the abluminal site, and the blood and its constituents on the luminal site [64]. The Ang/Tie system certainly functions as one of the junctions in signal transduction and plays a key role in multiple cellular processes, many of which have been linked to MODS.

\section{Targeting the Ang/Tie system in critical illness}

A therapy should intervene in the right place and at the right time, with the proper duration of action and without collateral damage $[156,157]$. The Ang/Tie system is involved in many processes and lies at the intersection of molecular mechanisms of disease. Thus, interventions targeting this system might have benefits. As in other pleiotropic systems, however, unexpected and unwanted side effects are a serious risk. The absence of redundant systems to take over the function of Ang/Tie2 has the advantage that the effect of therapeutic intervention cannot easily be bypassed by the cell. On the other hand, because the cell has no escape, the effect may become uncontrolled and irreversible. Moreover, the exact function of the Ang/Tie system in the pathological cascade is not fully established. What we see in animal models and in patients is most probably the systemic reflection of a local process. We do not know whether this systemic reflection is just a marker of organ injury or even a mediator of distant organ involvement.

Of the three main functions of the Ang/Tie system, it is mainly angiogenesis that has been evaluated as a therapeutic target. So far, the focus of Ang/Tie modulation has been on inhibiting angiogenesis related to malignant and ophthalmological diseases and to complications of diabetes [158,159]. In peripheral arterial occlusive disease, stimulation of angiogenesis seems a logical strategy to attenuate the consequences of ongoing tissue ischaemia. In a rat model of hind limb ischaemia, combined delivery of Ang-1 and VEGF genes stimulated collateral vessel development to the greatest extent $[160,161]$. Thus far, therapy directed at VEGF has reached the clinic, but not therapy directed at Ang/Tie [162].

Targeting homeostasis and repair/inflammation in critically ill patients is an attractive option and has already led to the development of new drugs $[45,158,163]$. From current knowledge, one can speculate about the best options for therapy aimed at the Ang/Tie system. In critical illness, Ang-1 is considered to be the 'good guy' because it can create vascular stability and thus its activity should be supported. In contrast, Ang-2 appears to be a 'bad guy' that induces vascular leakage, so its activity should be inhibited [164].

Production of recombinant Ang-1 is technically challenging as Ang-1 is 'sticky' because of its high affinity for the extracellular matrix [165]. However, stable Ang-1 variants with improved receptor affinity have been engineered. A stable soluble Ang-1 variant has anti-permeability activity [165]. When injected intraperitoneally in mice, human 
recombinant Ang-1 can prevent LPS-induced lung hyperpermeability [80]. In diabetic mice, a stable Ang-1 derivative attenuated proteinuria and delayed renal failure [166], and manipulating the Ang-1/Ang-2 ratio changed infarct size [167]. A more profound Ang-1 effect can be achieved by locally stimulating Ang-1 production. In experimental acute respiratory distress syndrome, transfected cells expressing Ang-1 reduced alveolar inflammation and leakage [130]. An adenovirus construct encoding Ang-1 protected mice from death in an LPS model, and Ang-1 gene therapy reduced acute lung injury in a rat model $[21,168,169]$. In hypertensive rats, a plasmid expressing a stable Ang-1 protein reduced blood pressure and end-organ damage [170]. If used in a disease with a limited duration, as critical illness should be, virus/plasmid-driven production of Ang-1 could easily be shut down when it is no longer needed.

Manipulating Ang-2 activity is also difficult. Ang-2 stored in WPBs is rapidly released and must be captured immediately to prevent autocrine/paracrine disruption of protective Ang-1/ Tie signalling. Soluble Tie2 or Ang-2 inhibitors should be effective [26,171]. Neutralizing antibodies against Ang-2 might also be an option. Replenishment of Ang-2 stores could be abolished by small interfering RNA techniques or spiegelmer/aptamer approaches $[25,172,173]$.

However, no bad guy is all bad, and no good guy is all good. For example, Ang-1 has been linked to the development of pulmonary hypertension [174]. Also, under certain circumstances Ang-2 can act as a Tie2 agonist and exert effects similar to those of Ang-1 - an unexplained finding that illustrates our limited understanding of the Ang/Tie system [75]. Complete blockade of Ang-2 might also hamper innate immunity and revascularization.

Finding the right balance and timing will be the major challenge when developing therapies to target the Ang/Tie system. In the meantime, we might have already used Ang/Tie-directed therapy with the most pleiotropic of all drugs - corticosteroids. In the airways, steroids suppressed Ang-2 and increased Ang-1 expression [26,171,175]. Interventions further downstream targeting specific adaptor molecules, signalling pathways, or transcription factors have yet to be explored.

\section{Diagnostic and prognostic opportunities}

In patients with malignant disease, the Ang/Tie system might serve as a tumour or response marker. In patients with multiple myeloma, normalization of the Ang-1/Ang-2 ratio reflects a response to treatment with anti-angiogenesis medication [176]. In patients with non-small-cell lung cancer, Ang-2 is increased in serum and indicates tumour progression [177]. After allogeneic stem cell transplantation in patients with high-risk myeloid malignancies, the serum Ang-2 concentration predicts disease-free survival [178], possibly reflecting a relation between cancer-driven angiogenesis and Ang-2 serum level.
In nonmalignant disease, the levels of Ang/Tie system components correlate with disease severity $[28,29,34-37,39]$. However, current data are insufficient to justify the use of serum soluble Tie2/Ang levels for diagnostic and prognostic purposes. In critical illness, assessment of the Ang/Tie system in patients with different severities of disease and with involvement of different organ systems might help to define our patient population and allow us to rethink our concepts of MODS. In this way, such work may lead to enhanced diagnosis and prognostication in the future [2].

\section{Conclusions}

Accumulating evidence from animal and human studies points to the involvement of the Ang/Tie system in vascular barrier dysfunction during critical illness. Many processes in injury and in repair act through this nonredundant system. Thus far, only preliminary studies in critically ill patients have been reported. Methods to manipulate this system are available but have not been tested in such patients. The response to treatment is difficult to predict because of the pleiotropic functions of the Ang/Tie system, because the balance among its components appears to be more important than the absolute levels, and because the sensitivity of the endothelium to disease-related stimuli varies, depending on the environment and the organ involved. To avoid disappointment, further experimental and translational research must be carried out, and Ang/Tie modulation must not be introduced into the clinic prematurely. Implementing the results of this research in critical care represents an opportunity to show what we have learned [2]. Ang/Tie signalling is a very promising target and must not be allowed to become lost in translation [179].

\section{Competing interests}

The author(s) declare that they have no competing interests.

\section{References}

1. Wenzel RP: Treating sepsis. N Engl J Med 2002, 347:966-967.

2. Marshall JC: Sepsis: rethinking the approach to clinical research. J Leukoc Biol 2008, 83:471-482.

3. Singer M, De Santis V, Vitale D, Jeffcoate W: Multiorgan failure is an adaptive, endocrine-mediated, metabolic response to overwhelming systemic inflammation. Lancet 2004, 364:545548.

4. Bone RC: Sir Isaac Newton, sepsis, SIRS, and CARS. Crit Care Med 1996, 24:1125-1128.

5. Hotchkiss RS, Swanson PE, Freeman BD, Tinsley KW, Cobb JP, Matuschak GM, Buchman TG, Karl IE: Apoptotic cell death in patients with sepsis, shock, and multiple organ dysfunction. Crit Care Med 1999, 27:1230-1251.

6. Rius J, Guma M, Schachtrup C, Akassoglou K, Zinkernagel AS, Nizet V, Johnson RS, Haddad GG, Karin M: NF-kappaB links innate immunity to the hypoxic response through transcriptional regulation of HIF-1alpha. Nature 2008, 453:807-811.

7. Bernard GR, Vincent JL, Laterre PF, LaRosa SP, Dhainaut JF, Lopez-Rodriguez A, Steingrub JS, Garber GE, Helterbrand JD, Ely EW, Fisher CJ Jr: Efficacy and safety of recombinant human activated protein C for severe sepsis. N Engl J Med 2001, 344: 699-709.

8. Annane D, Sebille V, Charpentier C, Bollaert PE, Francois B, Korach JM, Capellier G, Cohen Y, Azoulay E, Troche G, ChaumetRiffaut $P$, Bellissant $E$ : Effect of treatment with low doses of hydrocortisone and fludrocortisone on mortality in patients 
with septic shock. JAMA 2002, 288:862-871.

9. Van den Berghe G, Wouters P, Weekers F, Verwaest C, Bruyninckx F, Schetz M, Vlasselaers D, Ferdinande P, Lauwers P, Bouillon R: Intensive insulin therapy in the critically ill patients. $N$ Engl J Med 2001, 345:1359-1367.

10. Aird WC: Phenotypic heterogeneity of the endothelium: I. Structure, function, and mechanisms. Circ Res 2007, 100:158173.

11. Aird WC: Phenotypic heterogeneity of the endothelium: II. Representative vascular beds. Circ Res 2007, 100:174-190.

12. van Meurs M, Wulfert FM, Knol AJ, de Haes A, Houwertjes M, Aarts LP, Molema G: Early organ-specific endothelial activation during hemorrhagic shock and resuscitation. Shock 2008, 29: 291-299.

13. Langenkamp E, Molema G: Microvascular endothelial cell heterogeneity: general concepts and pharmacological consequences for anti-angiogenic therapy of cancer. Cell Tissue Res 2009, 335:205-222.

14. Aird WC: The role of the endothelium in severe sepsis and multiple organ dysfunction syndrome. Blood 2003, 101:37653777.

15. Bouis D, Kusumanto $\mathrm{Y}$, Meijer C, Mulder $\mathrm{NH}$, Hospers GA: A review on pro- and anti-angiogenic factors as targets of clinical intervention. Pharmacol Res 2006, 53:89-103.

16. Rafat N, Hanusch C, Brinkkoetter PT, Schulte J, Brade J, Zijlstra JG, van der Woude FJ, van AK, Yard BA, Beck GC: Increased circulating endothelial progenitor cells in septic patients: correlation with survival. Crit Care Med 2007, 35:1677-1684.

17. Brindle NP, Saharinen $P$, Alitalo K: Signaling and functions of angiopoietin-1 in vascular protection. Circ Res 2006, 98:10141023.

18. Jones PF: Not just angiogenesis: wider roles for the angiopoietins. J Pathol 2003, 201:515-527.

19. Davis B, Dei CA, Long DA, White KE, Hayward A, Ku CH, Woolf AS, Bilous R, Viberti G, Gnudi L: Podocyte-specific expression of angiopoietin-2 causes proteinuria and apoptosis of glomerular endothelia. J Am Soc Nephrol 2007, 18:2320-2329.

20. Campean V, Karpe B, Haas C, Atalla A, Peters H, Rupprecht H, Liebner S, Acker T, Plate K, Amann K: Angiopoietin 1 and 2 gene and protein expression is differentially regulated in acute anti-Thy1.1 glomerulonephritis. Am J Physiol Renal Physio/ 2008, 294:F1174-F1184.

21. McCarter SD, Mei SH, Lai PF, Zhang OW, Parker $\mathrm{CH}$, Suen RS, Hood RD, Zhao YD, Deng Y, Han RN, Dumont DJ, Stewart DJ: Cell-based angiopoietin-1 gene therapy for acute lung injury. Am J Respir Crit Care Med 2007, 175:1014-1026.

22. Simoes DC, Vassilakopoulos T, Toumpanakis D, Petrochilou K, Roussos C, Papapetropoulos A: Angiopoietin-1 protects against airway inflammation and hyperreactivity in asthma. Am J Respir Crit Care Med 2008, 177:1314-1321.

23. Kugathasan L, Dutly AE, Zhao YD, Deng Y, Robb MJ, Keshavjee $S$, Stewart DJ: Role of angiopoietin-1 in experimental and human pulmonary arterial hypertension. Chest 2005, 128 (suppl):633S-642S

24. Rudge JS, Thurston G, Yancopoulos GD: Angiopoietin-1 and pulmonary hypertension: cause or cure? Circ Res 2003, 92: 947-949.

25. Bhandari V, Choo-Wing R, Lee CG, Zhu Z, Nedrelow JH, Chupp GL, Zhang X, Matthay MA, Ware LB, Homer RJ, Lee PJ, Geick A, de Fougerolles AR, Elias JA: Hyperoxia causes angiopoietin 2mediated acute lung injury and necrotic cell death. Nat Med 2006, 12:1286-1293.

26. Kanazawa $H$, Nomura $S$, Asai K: Roles of angiopoietin-1 and angiopoietin-2 on airway microvascular permeability in asthmatic patients. Chest 2007, 131:1035-1041.

27. Kalomenidis I, Kollintza A, Sigala I, Papapetropoulos A, Papiris S, Light RW, Roussos C: Angiopoietin-2 levels are elevated in exudative pleural effusions. Chest 2006, 129:1 259-1266.

28. Parikh SM, Mammoto T, Schultz A, Yuan HT, Christiani D, Karumanchi SA, Sukhatme VP: Excess circulating angiopoietin-2 may contribute to pulmonary vascular leak in sepsis in humans. PLoS Med 2006, 3:e46.

29. Gallagher DC, Parikh SM, Balonov K, Miller A, Gautam S, Talmor $\mathrm{D}$, Sukhatme VP: Circulating angiopoietin 2 correlates with mortality in a surgical population with acute lung injury/adult respiratory distress syndrome. Shock 2008, 29:656-661.

30. Choudhury A, Freestone B, Patel J, Lip GY: Relationship of soluble CD40 ligand to vascular endothelial growth factor, angiopoietins, and tissue factor in atrial fibrillation: a link among platelet activation, angiogenesis, and thrombosis? Chest 2007, 132:1913-1919.

31. Nadar SK, Blann A, Beevers DG, Lip GY: Abnormal angiopoietins $1 \& 2$, angiopoietin receptor Tie-2 and vascular endothelial growth factor levels in hypertension: relationship to target organ damage [a sub-study of the Anglo-Scandinavian Cardiac Outcomes Trial (ASCOT)]. J Intern Med 2005, 258: 336-343.

32. Chong AY, Caine GJ, Freestone B, Blann AD, Lip GY: Plasma angiopoietin-1, angiopoietin-2, and angiopoietin receptor tie-2 levels in congestive heart failure. J Am Coll Cardiol 2004, 43: 423-428.

33. Lee KW, Lip GY, Blann AD: Plasma angiopoietin-1, angiopoietin-2, angiopoietin receptor tie-2, and vascular endothelial growth factor levels in acute coronary syndromes. Circulation 2004, 110:2355-2360.

34. Ganter MT, Cohen MJ, Brohi K, Chesebro BB, Staudenmayer KL, Rahn P, Christiaans SC, Bir ND, Pittet JF: Angiopoietin-2, marker and mediator of endothelial activation with prognostic significance early after trauma? Ann Surg 2008, 247:320-326.

35. Giuliano JS Jr, Lahni PM, Harmon K, Wong HR, Doughty LA, Carcillo JA, Zingarelli B, Sukhatme VP, Parikh SM, Wheeler DS: Admission angiopoietin levels in children with septic shock. Shock 2007, 28:650-654.

36. Lukasz A, Hellpap J, Horn R, Kielstein JT, David S, Haller H, Kumpers $\mathrm{P}$ : Circulating angiopoietin-1 and -2 in critically ill patients - development and clinical application of two new immunoassays. Crit Care 2008, 12:R94.

37. Orfanos SE, Kotanidou A, Glynos C, Athanasiou C, Tsigkos S, Dimopoulou I, Sotiropoulou C, Zakynthinos S, Armaganidis A, Papapetropoulos A, Roussos C: Angiopoietin-2 is increased in severe sepsis: correlation with inflammatory mediators. Crit Care Med 2007, 35:199-206.

38. Siner JM, Bhandari V, Engle KM, Elias JA, Siegel MD: Elevated serum angiopoietin 2 levels are associated with increased mortality in sepsis. Shock 2008 [Epub ahead of print].

39. van der Heijden M, Nieuw Amerongen GP, Koolwijk $P$, van Hinsbergh VW, Groeneveld AB: Angiopoietin-2, permeability oedema, occurrence and severity of ALI/ARDS in septic and non-septic critically ill patients. Thorax 2008, 63:903-909.

40. Shapiro NI, Yano K, Okada H, Fischer C, Howell M, Spokes KC, Ngo L, Angus DC, Aird WC: A prospective, observational study of soluble FLT-1 and vascular endothelial growth factor in sepsis. Shock 2008, 29:452-457.

41. van der Flier M, van Leeuwen $\mathrm{HJ}$, van Kessel KP, Kimpen JL, Hoepelman Al, Geelen SP: Plasma vascular endothelial growth factor in severe sepsis. Shock 2005, 23:35-38.

42. Pickkers $P$, Sprong T, Eijk L, van der Hoeven H, Smits $P$, Deuren $M$ : Vascular endothelial growth factor is increased during the first 48 hours of human septic shock and correlates with vascular permeability. Shock 2005, 24:508-512.

43. Suri C, Jones PF, Patan S, Bartunkova S, Maisonpierre PC, Davis S, Sato TN, Yancopoulos GD: Requisite role of angiopoietin-1, a ligand for the TIE2 receptor, during embryonic angiogenesis. Cell 1996, 87:1171-1180.

44. Maisonpierre PC, Suri C, Jones PF, Bartunkova S, Wiegand SJ, Radziejewski C, Compton D, McClain J, Aldrich TH, Papadopoulos N, Daly TJ, Davis S, Sato TN, Yancopoulos GD: Angiopoietin2, a natural antagonist for Tie2 that disrupts in vivo angiogenesis. Science 1997, 277:55-60.

45. Makinde T, Agrawal DK: Intra and extravascular transmembrane signalling of angiopoietin-1-Tie2 receptor in health and disease. J Cell Mol Med 2008, 12:810-828.

46. Davis S, Aldrich TH, Jones PF, Acheson A, Compton DL, Jain V, Ryan TE, Bruno J, Radziejewski C, Maisonpierre PC, Yancopoulos GD: Isolation of angiopoietin-1, a ligand for the TIE2 receptor, by secretion-trap expression cloning. Cell 1996, 87:11611169.

47. Jones N, Iljin K, Dumont DJ, Alitalo K: Tie receptors: new modulators of angiogenic and lymphangiogenic responses. Nat Rev Mol Cell Biol 2001, 2:257-267.

48. Kim KT, Choi HH, Steinmetz MO, Maco B, Kammerer RA, Ahn SY, Kim HZ, Lee GM, Koh GY: Oligomerization and multimerization are critical for angiopoietin-1 to bind and phosphorylate Tie2. J Biol Chem 2005, 280:20126-20131. 
49. Davis S, Papadopoulos N, Aldrich TH, Maisonpierre PC, Huang T, Kovac L, Xu A, Leidich R, Radziejewska E, Rafique A, Goldberg J, Jain V, Bailey K, Karow M, Fandl J, Samuelsson SJ, loffe E, Rudge JS, Daly TJ, Radziejewski C, Yancopoulos GD: Angiopoietins have distinct modular domains essential for receptor binding, dimerization and superclustering. Nat Struct Bio/ 2003, 10:3844.

50. Bogdanovic E, Nguyen VP, Dumont DJ: Activation of Tie2 by angiopoietin-1 and angiopoietin-2 results in their release and receptor internalization. J Cell Sci 2006, 119:3551-3560.

51. Peters KG, Kontos CD, Lin PC, Wong AL, Rao $P$, Huang $L$, Dewhirst MW, Sankar S: Functional significance of Tie2 signaling in the adult vasculature. Recent Prog Horm Res 2004, 59: 51-71.

52. Macdonald PR, Progias P, Ciani B, Patel S, Mayer U, Steinmetz $\mathrm{MO}$, Kammerer RA: Structure of the extracellular domain of Tie receptor tyrosine kinases and localization of the angiopoietinbinding epitope. J Biol Chem 2006, 281:28408-28414.

53. Hubbard SR, Till JH: Protein tyrosine kinase structure and function. Annu Rev Biochem 2000, 69:373-398.

54. Eklund L, Olsen BR: Tie receptors and their angiopoietin ligands are context-dependent regulators of vascular remodeling. Exp Cell Res 2006, 312:630-641.

55. Jones N, Master Z, Jones J, Bouchard D, Gunji Y, Sasaki H, Daly $\mathrm{R}$, Alitalo K, Dumont DJ: Identification of Tek/Tie2 binding partners. Binding to a multifunctional docking site mediates cell survival and migration. J Biol Chem 1999, 274:30896-30905.

56. Reusch P, Barleon B, Weindel K, Martiny-Baron G, Godde A, Siemeister G, Marme D: Identification of a soluble form of the angiopoietin receptor TIE-2 released from endothelial cells and present in human blood. Angiogenesis 2001, 4:123-131.

57. Findley CM, Cudmore MJ, Ahmed A, Kontos CD: VEGF induces Tie2 shedding via a phosphoinositide 3-kinase/Akt dependent pathway to modulate Tie2 signaling. Arterioscler Thromb Vasc Biol 2007, 27:2619-2626.

58. Marron MB, Singh H, Tahir TA, Kavumkal J, Kim HZ, Koh GY, Brindle NP: Regulated proteolytic processing of Tie1 modulates ligand responsiveness of the receptor-tyrosine kinase Tie2. J Biol Chem 2007, 282:30509-30517.

59. Yuan HT, Venkatesha S, Chan B, Deutsch U, Mammoto T, Sukhatme VP, Woolf AS, Karumanchi SA: Activation of the orphan endothelial receptor Tie1 modifies Tie2-mediated intracellular signaling and cell survival. FASEB J 2007, 21: 3171-3183.

60. Kim KL, Shin IS, Kim JM, Choi JH, Byun J, Jeon ES, Suh W, Kim DK: Interaction between Tie receptors modulates angiogenic activity of angiopoietin2 in endothelial progenitor cells. Cardiovasc Res 2006, 72:394-402.

61. Hirschberg R, Wang S, Mitu GM: Functional symbiosis between endothelium and epithelial cells in glomeruli. Cell Tissue Res 2008, 331:485-493.

62. Wong AL, Haroon ZA, Werner S, Dewhirst MW, Greenberg CS, Peters KG: Tie2 expression and phosphorylation in angiogenic and quiescent adult tissues. Circ Res 1997, 81:567-574.

63. Armulik A, Abramsson A, Betsholtz C: Endothelial/pericyte interactions. Circ Res 2005, 97:512-523.

64. Bergers G, Song S: The role of pericytes in blood-vessel formation and maintenance. Neuro Oncol 2005, 7:452-464.

65. Saharinen $P$, Eklund $L$, Miettinen J, Wirkkala R, Anisimov A, Winderlich M, Nottebaum A, Vestweber D, Deutsch U, Koh GY, Olsen BR, Alitalo K: Angiopoietins assemble distinct Tie2 signalling complexes in endothelial cell-cell and cell-matrix contacts. Nat Cell Biol 2008, 10:527-537.

66. Metcalf DJ, Nightingale TD, Zenner HL, Lui-Roberts WW, Cutler DF: Formation and function of Weibel-Palade bodies. $J$ Cell Sci $2008,121: 19-27$

67. Fiedler U, Scharpfenecker M, Koidl S, Hegen A, Grunow V, Schmidt JM, Kriz W, Thurston G, Augustin HG: The Tie-2 ligand angiopoietin-2 is stored in and rapidly released upon stimulation from endothelial cell Weibel-Palade bodies. Blood 2004, 103:4150-4156

68. Rondaij MG, Bierings $R$, Kragt $A$, van Mourik JA, Voorberg J: Dynamics and plasticity of Weibel-Palade bodies in endothelial cells. Arterioscler Thromb Vasc Biol 2006, 26:1002-1007.

69. Lewis CE, De PM, Naldini L: Tie2-expressing monocytes and tumor angiogenesis: regulation by hypoxia and angiopoietin2. Cancer Res 2007, 67:8429-8432.
70. De Palma M., Murdoch C, Venneri MA, Naldini L, Lewis CE: Tie2expressing monocytes: regulation of tumor angiogenesis and therapeutic implications. Trends Immuno/ 2007, 28:519-524.

71. Yoon MJ, Cho CH, Lee CS, Jang IH, Ryu SH, Koh GY: Localization of Tie2 and phospholipase D in endothelial caveolae is involved in angiopoietin-1-induced MEK/ERK phosphorylation and migration in endothelial cells. Biochem Biophys Res Commun 2003, 308:101-105.

72. Ward EG, Grosios K, Markham AF, Jones PF: Genomic structures of the human angiopoietins show polymorphism in angiopoietin-2. Cytogenet Cell Genet 2001, 94:147-154.

73. Oh H, Takagi $H$, Suzuma K, Otani A, Matsumura M, Honda $Y$ : Hypoxia and vascular endothelial growth factor selectively upregulate angiopoietin-2 in bovine microvascular endothelial cells. J Biol Chem 1999, 274:15732-15739.

74. Mandriota SJ, Pepper MS: Regulation of angiopoietin-2 mRNA levels in bovine microvascular endothelial cells by cytokines and hypoxia. Circ Res 1998, 83:852-859.

75. Daly C, Pasnikowski E, Burova E, Wong V, Aldrich TH, Griffiths J, loffe E, Daly TJ, Fandl JP, Papadopoulos N, McDonald DM, Thurston G, Yancopoulos GD, Rudge JS: Angiopoietin-2 functions as an autocrine protective factor in stressed endothelial cells. Proc Natl Acad Sci USA 2006, 103:15491-15496.

76. Hegen A, Koidl S, Weindel K, Marme D, Augustin HG, Fiedler U: Expression of angiopoietin-2 in endothelial cells is controlled by positive and negative regulatory promoter elements. Arterioscler Thromb Vasc Biol 2004, 24:1803-1809.

77. Hasegawa Y, Abe M, Yamazaki T, Niizeki O, Shiiba K, Sasaki I, Sato $Y$ : Transcriptional regulation of human angiopoietin-2 by transcription factor Ets-1. Biochem Biophys Res Commun 2004, 316:52-58.

78. Park EH, Lee JM, Blais JD, Bell JC, Pelletier J: Internal translation initiation mediated by the angiogenic factor Tie2. J Biol Chem 2005, 280:20945-20953

79. Mehta $D$, Malik AB: Signaling mechanisms regulating endothelial permeability. Physiol Rev 2006, 86:279-367.

80. Mammoto T, Parikh SM, Mammoto A, Gallagher D, Chan B, Mostoslavsky G, Ingber DE, Sukhatme VP: Angiopoietin-1 requires p190 RhoGAP to protect against vascular leakage in vivo. J Biol Chem 2007, 282:23910-23918.

81. Abdel-Malak NA, Harfouche R, Hussain SN: Transcriptome of angiopoietin 1-activated human umbilical vein endothelial cells. Endothelium 2007, 14:285-302.

82. Chen $\mathrm{SH}$, Babichev $\mathrm{Y}$, Rodrigues N, Voskas D, Ling L, Nguyen VP, Dumont DJ: Gene expression analysis of Tek/Tie2 signaling. Physiol Genomics 2005, 22:257-267.

83. Babaei S, Teichert-Kuliszewska K, Zhang Q, Jones N, Dumont DJ, Stewart DJ: Angiogenic actions of angiopoietin-1 require endothelium-derived nitric oxide. Am J Pathol 2003, 162:19271936.

84. Harfouche R, Hassessian HM, Guo Y, Faivre V, Srikant CB, Yancopoulos GD, Hussain SN: Mechanisms which mediate the antiapoptotic effects of angiopoietin-1 on endothelial cells. Microvasc Res 2002, 64:135-147.

85. Kim I, Kim HG, Moon SO, Chae SW, So JN, Koh KN, Ahn BC, Koh GY: Angiopoietin-1 induces endothelial cell sprouting through the activation of focal adhesion kinase and plasmin secretion. Circ Res 2000, 86:952-959.

86. Brkovic A, Pelletier M, Girard D, Sirois MG: Angiopoietin chemotactic activities on neutrophils are regulated by $\mathrm{PI}-3 \mathrm{~K}$ activation. J Leukoc Bio/ 2007, 81:1093-1101.

87. Harfouche R, Gratton JP, Yancopoulos GD, Noseda M, Karsan A, Hussain SN: Angiopoietin-1 activates both anti- and proapoptotic mitogen-activated protein kinases. FASEB J 2003, 17: 1523-1525.

88. Harfouche R, Hussain SN: Signaling and regulation of endothelial cell survival by angiopoietin-2. Am J Physiol Heart Circ Physiol 2006, 291:H1635-H1645.

89. Kim I, Kim JH, Moon SO, Kwak HJ, Kim NG, Koh GY: Angiopoietin-2 at high concentration can enhance endothelial cell survival through the phosphatidylinositol 3'-kinase/Akt signal transduction pathway. Oncogene 2000, 19:4549-4552.

90. Maliba R, Lapointe S, Neagoe PE, Brkovic A, Sirois MG: Angiopoietins -1 and -2 are both capable of mediating endothelial PAF synthesis: intracellular signalling pathways. Cell Signal 2006, 18:1947-1957.

91. Abdel-Malak NA, Srikant CB, Kristof AS, Magder SA, Di Battista 
JA, Hussain SN: Angiopoietin-1 promotes endothelial cell proliferation and migration through AP-1-dependent autocrine production of interleukin-8. Blood 2008, 111:4145-4154.

92. Daly C, Wong V, Burova E, Wei Y, Zabski S, Griffiths J, Lai KM, Lin HC, loffe E, Yancopoulos GD, Rudge JS: Angiopoietin-1 modulates endothelial cell function and gene expression via the transcription factor FKHR (FOXO1). Genes Dev 2004, 18: 1060-1071.

93. Tadros A, Hughes DP, Dunmore BJ, Brindle NP: ABIN-2 protects endothelial cells from death and has a role in the antiapoptotic effect of angiopoietin-1. Blood 2003, 102:4407-4409.

94. Harfouche R, Malak NA, Brandes RP, Karsan A, Irani K, Hussain $\mathrm{SN}$ : Roles of reactive oxygen species in angiopoietin-1/tie-2 receptor signaling. FASEB J 2005, 19:1728-1730.

95. Fukuhara S, Sako K, Minami T, Noda K, Kim HZ, Kodama T, Shibuya M, Takakura N, Koh GY, Mochizuki N: Differential function of Tie2 at cell-cell contacts and cell-substratum contacts regulated by angiopoietin-1. Nat Cell Biol 2008, 10:513-526.

96. Lobov IB, Brooks PC, Lang RA: Angiopoietin-2 displays VEGFdependent modulation of capillary structure and endothelial cell survival in vivo. Proc Natl Acad Sci USA 2002, 99:1120511210 .

97. Nguyen VP, Chen SH, Trinh J, Kim H, Coomber BL, Dumont DJ: Differential response of lymphatic, venous and arterial endothelial cells to angiopoietin-1 and angiopoietin-2. BMC Cell Biol 2007, 8:10.

98. Teichert-Kuliszewska K, Maisonpierre PC, Jones N, Campbell Al, Master Z, Bendeck MP, Alitalo K, Dumont DJ, Yancopoulos GD, Stewart DJ: Biological action of angiopoietin-2 in a fibrin matrix model of angiogenesis is associated with activation of Tie2. Cardiovasc Res 2001, 49:659-670.

99. Imhof $B A$, urrand-Lions $M$ : Angiogenesis and inflammation face off. Nat Med 2006, 12:171-172.

100. Frantz S, Vincent KA, Feron O, Kelly RA: Innate immunity and angiogenesis. Circ Res 2005, 96:15-26.

101. Hamik A, Wang B, Jain MK: Transcriptional regulators of angiogenesis. Arterioscler Thromb Vasc Bio/ 2006, 26:1936-1947.

102. Davis GE, Senger DR: Extracellular matrix mediates a molecular balance between vascular morphogenesis and regression. Curr Opin Hematol 2008, 15:197-203.

103. Scharpfenecker M, Fiedler U, Reiss Y, Augustin HG: The Tie-2 ligand angiopoietin-2 destabilizes quiescent endothelium through an internal autocrine loop mechanism. J Cell Sci 2005, 118:771-780.

104. Aplin AC, Gelati M, Fogel E, Carnevale E, Nicosia RF: Angiopoietin-1 and vascular endothelial growth factor induce expression of inflammatory cytokines before angiogenesis. Physiol Genomics 2006, 27:20-28.

105. Uemura A, Ogawa M, Hirashima M, Fujiwara T, Koyama S, Takagi $\mathrm{H}$, Honda $Y$, Wiegand SJ, Yancopoulos GD, Nishikawa S: Recombinant angiopoietin-1 restores higher-order architecture of growing blood vessels in mice in the absence of mural cells. J Clin Invest 2002, 110:1619-1628.

106. Ramsauer M, D'Amore PA: Contextual role for angiopoietins and TGFbeta1 in blood vessel stabilization. J Cell Sci 2007, 120:1810-1817.

107. Kwak HJ, So JN, Lee SJ, Kim I, Koh GY: Angiopoietin-1 is an apoptosis survival factor for endothelial cells. FEBS Lett 1999, 448:249-253.

108. Papapetropoulos A, Garcia-Cardena G, Dengler TJ, Maisonpierre PC, Yancopoulos GD, Sessa WC: Direct actions of angiopoietin-1 on human endothelium: evidence for network stabilization, cell survival, and interaction with other angiogenic growth factors. Lab Invest 1999, 79:213-223.

109. Papapetropoulos A, Fulton D, Mahboubi K, Kalb RG, O'Connor DS, Li F, Altieri DC, Sessa WC: Angiopoietin-1 inhibits endothelial cell apoptosis via the Akt/survivin pathway. J Biol Chem 2000, 275:9102-9105

110. Morrow D, Cullen JP, Cahill PA, Redmond EM: Cyclic strain regulates the Notch/CBF-1 signaling pathway in endothelial cells: role in angiogenic activity. Arterioscler Thromb Vasc Biol 2007, 27:1289-1296.

111. Murdoch C, Tazzyman S, Webster S, Lewis CE: Expression of Tie- 2 by human monocytes and their responses to angiopoietin-2. J Immunol 2007, 178:7405-7411.

112. Chen-Konak L, Guetta-Shubin Y, Yahav H, Shay-Salit A, Zilberman M, Binah O, Resnick N: Transcriptional and post-transla- tion regulation of the Tie1 receptor by fluid shear stress changes in vascular endothelial cells. FASEB $J$ 2003, 17: 2121-2123.

113. Witzenbichler B, Maisonpierre PC, Jones P, Yancopoulos GD, Isner JM: Chemotactic properties of angiopoietin-1 and -2, ligands for the endothelial-specific receptor tyrosine kinase Tie2. J Biol Chem 1998, 273:18514-18521.

114. Rao S, Lobov IB, Vallance JE, Tsujikawa K, Shiojima I, Akunuru S, Walsh K, Benjamin LE, Lang RA: Obligatory participation of macrophages in an angiopoietin 2-mediated cell death switch. Development 2007, 134:4449-4458.

115. Roviezzo F, Tsigkos S, Kotanidou A, Bucci M, Brancaleone V, Cirino G, Papapetropoulos A: Angiopoietin-2 causes inflammation in vivo by promoting vascular leakage. J Pharmacol Exp Ther 2005, 314:738-744

116. Feraud O, Mallet C, Vilgrain I: Expressional regulation of the angiopoietin-1 and -2 and the endothelial-specific receptor tyrosine kinase Tie2 in adrenal atrophy: a study of adrenocorticotropin-induced repair. Endocrinology 2003, 144:4607-4615.

117. Fiedler U, Augustin HG: Angiopoietins: a link between angiogenesis and inflammation. Trends Immuno/ 2006, 27:552-558.

118. Baffert F, Le T, Thurston G, McDonald DM: Angiopoietin-1 decreases plasma leakage by reducing number and size of endothelial gaps in venules. Am J Physiol Heart Circ Physiol 2006, 290:H107-H118.

119. Thurston G, Rudge JS, loffe E, Zhou H, Ross L, Croll SD, Glazer N, Holash J, McDonald DM, Yancopoulos GD: Angiopoietin-1 protects the adult vasculature against plasma leakage. Nat Med 2000, 6:460-463.

120. Kim I, Oh JL, Ryu YS, So JN, Sessa WC, Walsh K, Koh GY: Angiopoietin-1 negatively regulates expression and activity of tissue factor in endothelial cells. FASEB J 2002, 16:126-128.

121. Gamble JR, Drew J, Trezise L, Underwood A, Parsons M, Kasminkas L, Rudge J, Yancopoulos G, Vadas MA: Angiopoietin-1 is an antipermeability and anti-inflammatory agent in vitro and targets cell junctions. Circ Res 2000, 87:603-607.

122. Kim I, Moon SO, Park SK, Chae SW, Koh GY: Angiopoietin-1 reduces VEGF-stimulated leukocyte adhesion to endothelial cells by reducing ICAM-1, VCAM-1, and E-selectin expression. Circ Res 2001, 89:477-479.

123. Pizurki L, Zhou Z, Glynos K, Roussos C, Papapetropoulos A: Angiopoietin-1 inhibits endothelial permeability, neutrophil adherence and IL-8 production. Br J Pharmacol 2003, 139:329336.

124. Satchell SC, Anderson KL, Mathieson PW: Angiopoietin 1 and vascular endothelial growth factor modulate human glomerular endothelial cell barrier properties. J Am Soc Nephrol 2004, 15:566-574.

125. Fiedler $U$, Reiss $Y$, Scharpfenecker $M$, Grunow $V$, Koidl $S$, Thurston G, Gale NW, Witzenrath M, Rosseau S, Suttorp N, Sobke A, Herrmann M, Preissner KT, Vajkoczy P, Augustin HG: Angiopoietin-2 sensitizes endothelial cells to TNF-alpha and has a crucial role in the induction of inflammation. Nat Med 2006, 12:235-239.

126. Park YS, Kim NH, Jo I: Hypoxia and vascular endothelial growth factor acutely up-regulate angiopoietin-1 and Tie2 mRNA in bovine retinal pericytes. Microvasc Res 2003, 65:125131.

127. Pichiule P, Chavez JC, LaManna JC: Hypoxic regulation of angiopoietin-2 expression in endothelial cells. J Biol Chem 2004, 279:12171-12180.

128. Mofarrahi M, Nouh T, Qureshi S, Guillot L, Mayaki D, Hussain SN: Regulation of angiopoietin expression by bacterial lipopolysaccharide. Am J Physiol Lung Cell Mol Physiol 2008, 294:L955-L963.

129. Karmpaliotis D, Kosmidou I, Ingenito EP, Hong K, Malhotra A, Sunday ME, Haley KJ: Angiogenic growth factors in the pathophysiology of a murine model of acute lung injury. $\mathrm{Am} J$ Physiol Lung Cell Mol Physiol 2002, 283:L585-L595.

130. Mei SH, McCarter SD, Deng Y, Parker CH, Liles WC, Stewart DJ: Prevention of LPS-induced acute lung injury in mice by mesenchymal stem cells overexpressing angiopoietin 1. PLOS Med 2007, 4:e269.

131. Hangai M, He S, Hoffmann S, Lim Jl, Ryan SJ, Hinton DR: Sequential induction of angiogenic growth factors by TNFalpha in choroidal endothelial cells. J Neuroimmunol 2006, 171:45-56. 
132. Kim I, Kim JH, Ryu YS, Liu M, Koh GY: Tumor necrosis factoralpha upregulates angiopoietin-2 in human umbilical vein endothelial cells. Biochem Biophys Res Commun 2000, 269: 361-365.

133. Hashimoto T, Wu Y, Boudreau N, Li J, Matsumoto M, Young W: Regulation of tie2 expression by angiopoietin-potential feedback system. Endothelium 2004, 11:207-210.

134. Mangan SH, Campenhout AV, Rush C, Golledge J: Osteoprotegerin upregulates endothelial cell adhesion molecule response to tumor necrosis factor-alpha associated with induction of angiopoietin-2. Cardiovasc Res 2007, 76:494-505.

135. Maliba R, Brkovic A, Neagoe PE, Villeneuve LR, Sirois MG: Angiopoietin-mediated endothelial P-selectin translocation: cell signaling mechanisms. J Leukoc Bio/ 2008, 83:352-360.

136. Bezuidenhout L, Bracher M, Davison G, Zilla P, Davies N: Ang-2 and PDGF-BB cooperatively stimulate human peripheral blood monocyte fibrinolysis. J Leukoc Biol 2007, 81:14961503.

137. Lemieux C, Maliba R, Favier J, Theoret JF, Merhi Y, Sirois MG: Angiopoietins can directly activate endothelial cells and neutrophils to promote proinflammatory responses. Blood 2005, 105:1523-1530.

138. Childs EW, Tharakan B, Byrge N, Tinsley JH, Hunter FA, Smythe WR: Angiopoietin-1 inhibits intrinsic apoptotic signaling and vascular hyperpermeability following hemorrhagic shock. Am J Physiol Heart Circ Physiol 2008, 294:H2285-H2295.

139. Dallabrida SM, Ismail N, Oberle JR, Himes BE, Rupnick MA: Angiopoietin-1 promotes cardiac and skeletal myocyte survival through integrins. Circ Res 2005, 96:e8-24.

140. Childs EW, Tharakan B, Hunter FA, Tinsley JH, Cao X: Apoptotic signaling induces hyperpermeability following hemorrhagic shock. Am J Physiol Heart Circ Physiol 2007, 292:H3179H3189.

141. Tharakan B, Holder-Haynes JG, Hunter FA, Childs EW: Alpha lipoic acid attenuates microvascular endothelial cell hyperpermeability by inhibiting the intrinsic apoptotic signaling. $A m$ J Surg 2008, 195:174-178.

142. Davidson MT, Deitch EA, Lu Q, Hasko G, Abungu B, Nemeth ZH, Zaets SB, Gaspers LD, Thomas AP, Xu DZ: Trauma-hemorrhagic shock mesenteric lymph induces endothelial apoptosis that involves both caspase-dependent and caspase-independent mechanisms. Ann Surg 2004, 240:123-131.

143. van der Heijden M, Versteilen AM, Sipkema $P$, van Nieuw Amerongen GP, Musters RJ, Groeneveld AB: Rho-kinase-dependent Factin rearrangement is involved in the inhibition of PI3-kinase/Akt during ischemia-reperfusion-induced endothelial cell apoptosis. Apoptosis 2008, 13:404-412.

144. Serini G, Napione L, Arese M, Bussolino F: Besides adhesion: new perspectives of integrin functions in angiogenesis. Cardiovasc Res 2008, 78:213-222.

145. Carlson TR, Feng Y, Maisonpierre PC, Mrksich M, Morla AO: Direct cell adhesion to the angiopoietins mediated by integrins. J Biol Chem 2001, 276:26516-26525.

146. Weber CC, Cai H, Ehrbar M, Kubota H, Martiny-Baron G, Weber W, Djonov V, Weber E, Mallik AS, Fussenegger M, Frei K, Hubbell $J A$, Zisch $A H$ : Effects of protein and gene transfer of the angiopoietin-1 fibrinogen-like receptor-binding domain on endothelial and vessel organization. J Biol Chem 2005, 280: 22445-22453

147. Dejana E, Orsenigo F, Lampugnani MG: The role of adherens junctions and VE-cadherin in the control of vascular permeability. J Cell Sci 2008, 121:2115-2122.

148. Shay-Salit A, Shushy M, Wolfovitz E, Yahav H, Breviario F, Dejana E, Resnick N: VEGF receptor 2 and the adherens junction as a mechanical transducer in vascular endothelial cells. Proc Natl Acad Sci USA 2002, 99:9462-9467.

149. Wang Y, Pampou S, Fujikawa K, Varticovski L: Opposing effect of angiopoietin-1 on VEGF-mediated disruption of endothelial cell-cell interactions requires activation of PKC beta. J Cell Physio/ 2004, 198:53-61.

150. Gavard J, Patel V, Gutkind JS: Angiopoietin-1 prevents VEGFinduced endothelial permeability by sequestering Src through mDia. Dev Cell 2008, 14:25-36.

151. Cascone I, Napione L, Maniero F, Serini G, Bussolino F: Stable interaction between alpha5beta1 integrin and Tie2 tyrosine kinase receptor regulates endothelial cell response to Ang-1. $J$ Cell Biol 2005, 170:993-1004.
152. David S, Kumpers P, Hellpap J, Horn R, Holger L, Kielstein JT, Haller $\mathrm{H}$ : Elevated serum angiopoietin-2 correlates with degree of arteriosclerosis in CKD V patients. J Am Soc Nephrol 2007, 18:SU-PO250 [http://www.asn-online.org/education_and_meetings/ renal_week/archives/2007-abstracts-archive.pdf]

153. Pfaff D, Fiedler U, Augustin HG: Emerging roles of the angiopoietin-Tie and the ephrin-Eph systems as regulators of cell trafficking. J Leukoc Bio/ 2006, 80:719-726.

154. Methe H, Hess S, Edelman ER: Endothelial immunogenicity: a matter of matrix microarchitecture. Thromb Haemost 2007, 98: 278-282.

155. Methe H, Balcells M, Alegret MC, Santacana M, Molins B, Hamik A, Jain MK, Edelman ER: Vascular bed origin dictates flow pattern regulation of endothelial adhesion molecule expression. Am J Physiol Heart Circ Physiol 2007, 292:H2167-H2175.

156. Griffioen AW, Molema G: Angiogenesis: potentials for pharmacologic intervention in the treatment of cancer, cardiovascular diseases, and chronic inflammation. Pharmacol Rev 2000, 52: 237-268.

157. Griffin RJ, Molema G, Dings RP: Angiogenesis treatment, new concepts on the horizon. Angiogenesis 2006, 9:67-72.

158. Niu Q, Perruzzi C, Voskas D, Lawler J, Dumont DJ, Benjamin LE: Inhibition of Tie-2 signaling induces endothelial cell apoptosis, decreases Akt signaling, and induces endothelial cell expression of the endogenous anti-angiogenic molecule, thrombospondin-1. Cancer Biol Ther 2004, 3:402-405.

159. Kerbel RS: Tumor angiogenesis. N Engl J Med 2008, 358: 2039-2049.

160. Chae JK, Kim I, Lim ST, Chung MJ, Kim WH, Kim HG, Ko JK, Koh GY: Coadministration of angiopoietin-1 and vascular endothelial growth factor enhances collateral vascularization. Arterioscler Thromb Vasc Biol 2000, 20:2573-2578.

161. Ryu JK, Cho CH, Shin HY, Song SU, Oh SM, Lee M, Piao S, Han JY, Kim IH, Koh GY, Suh JK: Combined angiopoietin-1 and vascular endothelial growth factor gene transfer restores cavernous angiogenesis and erectile function in a rat model of hypercholesterolemia. Mol Ther 2006, 13:705-715.

162. Holash J, Thurston G, Rudge JS, Yancopoulos GD, Adjei AA, Bergers G, Pytowski B, Pegram M, Gordon MS: Inhibitors of growth factor receptors, signaling pathways and angiogenesis as therapeutic molecular agents. Cancer Metastasis Rev 2006, 25:243-252.

163. Koh GY, Kim I, Kwak HJ, Yun MJ, Leem JC: Biomedical significance of endothelial cell specific growth factor, angiopoietin. Exp Mol Med 2002, 34:1-11.

164. Hashimoto T, Pittet JF: Angiopoietin-2: modulator of vascular permeability in acute lung injury? PLoS Med 2006, 3:e113.

165. Cho CH, Kammerer RA, Lee HJ, Steinmetz MO, Ryu YS, Lee SH, Yasunaga K, Kim KT, Kim I, Choi HH, Kim W, Kim SH, Park SK, Lee GM, Koh GY: COMP-Ang1: a designed angiopoietin-1 variant with nonleaky angiogenic activity. Proc Natl Acad Sci USA 2004, 101:5547-5552.

166. Lee S, Kim W, Moon SO, Sung MJ, Kim DH, Kang KP, Jang KY Lee SY, Park BH, Koh GY, Park SK: Renoprotective effect of COMP-angiopoietin-1 in $\mathrm{db} / \mathrm{db}$ mice with type 2 diabetes. Nephrol Dial Transplant 2007, 22:396-408.

167. Tuo $\mathrm{QH}$, Zeng $\mathrm{H}$, Stinnett $A, Y u H$, Aschner JL, Liao DF, Chen JX: Critical role of angiopoietins/Tie-2 in hyperglycemic exacerbation of myocardial infarction and impaired angiogenesis. Am J Physiol Heart Circ Physiol 2008, 294:H2547-H2557.

168. Thebaud B, Ladha F, Michelakis ED, Sawicka M, Thurston G, Eaton F, Hashimoto K, Harry G, Haromy A, Korbutt G, Archer SL: Vascular endothelial growth factor gene therapy increases survival, promotes lung angiogenesis, and prevents alveolar damage in hyperoxia-induced lung injury: evidence that angiogenesis participates in alveolarization. Circulation 2005 112:2477-2486

169. Witzenbichler B, Westermann D, Knueppel S, Schultheiss HP Tschope C: Protective role of angiopoietin-1 in endotoxic shock. Circulation 2005, 111:97-105.

170. Lee JS, Song SH, Kim JM, Shin IS, Kim KL, Suh YL, Kim HZ, Koh GY, Byun J, Jeon ES, Suh W, Kim DK: Angiopoietin-1 prevents hypertension and target organ damage through its interaction with endothelial Tie2 receptor. Cardiovasc Res 2008, 78:572580.

171. Aghai ZH, Faqiri S, Saslow JG, Nakhla T, Farhath S, Kumar A, Eydelman R, Strande L, Stahl G, Leone P, Bhandari V: Angiopoi- 
etin 2 concentrations in infants developing bronchopulmonary dysplasia: attenuation by dexamethasone. J Perinatol 2008, 28:149-155.

172. Sarraf-Yazdi S, Mi J, Moeller BJ, Niu X, White RR, Kontos CD, Sullenger BA, Dewhirst MW, Clary BM: Inhibition of in vivo tumor angiogenesis and growth via systemic delivery of an angiopoietin 2-specific RNA aptamer. J Surg Res 2008, 146:16-23.

173. Grimm D, Kay MA: Therapeutic application of RNAi: is mRNA targeting finally ready for prime time? J Clin Invest 2007, 117: 3633-3641.

174. Dewachter L, Adnot S, Fadel E, Humbert M, Maitre B, Barlier-Mur AM, Simonneau G, Hamon M, Naeije R, Eddahibi S: Angiopoietin/Tie2 pathway influences smooth muscle hyperplasia in idiopathic pulmonary hypertension. Am J Respir Crit Care Med 2006, 174:1025-1033.

175. Nomura S, Kanazawa H, Hirata K, Iwao H, Yoshikawa J: Relationship between vascular endothelial growth factor and angiopoietin-2 in asthmatics before and after inhaled beclomethasone therapy. J Asthma 2005, 42:141-146.

176. Anargyrou K, Terpos E, Vassilakopoulos TP, Pouli A, Sachanas S, Tzenou T, Masouridis S, Christoulas D, Angelopoulou MK, Dimitriadou EM, Kalpadakis C, Tsionos K, Panayiotidis P, Dimopoulos MA, Pangalis GA, Kyrtsonis MC: Normalization of the serum angiopoietin-1 to angiopoietin-2 ratio reflects response in refractory/resistant multiple myeloma patients treated with bortezomib. Haematologica 2008, 93:451-454.

177. Park JH, Park KJ, Kim YS, Sheen SS, Lee KS, Lee HN, Oh YJ, Hwang SC: Serum angiopoietin-2 as a clinical marker for lung cancer. Chest 2007, 132:200-206.

178. Kumpers P, Koenecke C, Hecker H, Hellpap J, Horn R, Verhagen W, Buchholz S, Hertenstein B, Krauter J, Eder M, David S, Gohring G, Haller H, Ganser A: Angiopoietin-2 predicts disease-free survival after allogeneic stem cell transplantation in patients with high-risk myeloid malignancies. Blood 2008, 112:2139-2148.

179. Ledford H: The full cycle. Nature 2008, 453:843-845.

180. Gallagher DC, Bhatt RS, Parikh SM, Patel P, Seery V, McDermott DF, Atkins MB, Sukhatme VP: Angiopoietin 2 is a potential mediator of high-dose interleukin 2-induced vascular leak. Clin Cancer Res 2007, 13:2115-2120.

181. Scholz A, Rehm VA, Rieke S, Derkow K, Schulz P, Neumann K Koch I, Pascu M, Wiedenmann B, Berg T, Schott E: Angiopoietin-2 serum levels are elevated in patients with liver cirrhosis and hepatocellular carcinoma. Am J Gastroentero/ 2007, 102: 2471-2481. 